\title{
The reception history of Beowulf
}

\author{
Robert E. Bjork \\ Arizona State University
}

This paper traces both the scholarly and popular reception of the Old English epic Beowulf from the publication of the first edition of the poem in 1815 to the most recent English novel based on it from 2019. Once the work was first made available to the scholarly community, numerous editions in various languages began to appear, the most recent being in English from 2008; once editions were published, Old English scholars around the world could translate the text into their native languages beginning with Danish in 1820. Translations, in their turn, made the poem available to a general audience, which responded to the poem through an array of media: music, art, poetry, prose fiction, plays, film, television, video games, comic books, and graphic novels. The enduring, widespread appeal of the poem remains great and universal.

Keywords: adaptation; Beowulf; cultural influence; reception history; transmission history

From a unique, obscure manuscript housed in the British Library, ${ }^{1}$ Beowulf emerged into the modern world in 1815 with the publication of the first edition of the poem accompanied by Latin apparatus and a facing-page Latin translation (Thorkelin 1815). The epic had languished in obscurity for some 800 years. Humfrey Wanley noted its existence in his 1705 catalogue of Anglo-Saxon manuscripts and even transcribed lines 1-19 and 53-73 of it (Wanley 1705: 218219), but otherwise the poem remained unnoticed, unmentioned, unappreciated. ${ }^{2}$ Since 1815 , however, it has experienced a host of scholarly and

${ }^{1}$ Cotton Vitellius A xv contains five texts, including Beowulf. For an edition and facingpage English translation of the entire manuscript, see Fulk (2010).

${ }^{2}$ The historian Sharon Turner does briefly mention the poem and its listing in Wanley's catalogue in Turner (1803: 11) and again in Turner (1805: 398-408), where he

Robert E. Bjork, Selim25 (2020): 1-19.

ISSN 1132-631X / DOI: https://doi.org/10.17811/selim.25.2020.1-20 
popular cultural migrations that testify to its power, international stature, and longevity.

The migration story begins in 1785 when Grímur Jónsson Thorkelin, a Danish/Icelandic scholar who would be appointed Keeper of the Danish National Archives in 1790, sailed from Copenhagen to England on a nationalistic voyage to collect any documents he could find related to Danish and Norwegian history and bring as many of them back to Denmark as possible (Anonymous 1897; see also Bjork 1996: 293-294). Discovering the Beowulf manuscript, undoubtedly with the aid of Wanley's catalogue, ${ }^{3}$ he had the poem transcribed in 1787 and subsequently transcribed it himself. These two transcriptions, called Thorkelin A and Thorkelin B, represent the poem's first migration in its entirety from near oblivion into the modern world. ${ }^{4}$ The audience for the transcriptions - just Thorkelin himself - was extremely limited, however. His resultant edition of the poem from 1815 is what truly inaugurates the poem's international diaspora even though the audience, much greater than one, was still restricted and still highly specialized since both the scholarly apparatus and the facing-page translation were in Latin. That first complete edition, which was universally excoriated, ${ }^{5}$ was followed by over thirty others in English, Danish, German, and French, ${ }^{6}$ and the secondary scholarship based on that multitude of editions is voluminous. It still grows exponentially every year in several languages around the world. ${ }^{7}$

The editions of Beowulf with apparatus in various vernacular tongues considerably expanded the audience for the poem and also made possible its translation into twenty-nine of the world's major (including Japanese, Korean, and Chinese) and minor (including Telugu) languages. ${ }^{8}$ In Chinese alone, three

summarizes the poem and supplies English translations in verse and prose of several sections. No other record exists of the poem's having attracted anyone else's attention. ${ }^{3}$ Thorkelin may have been alerted to Wanley's catalogue entry by Jacob Langebek, whom he would succeed as Danish National Archivist. See Shippey \& Haarder (1998: 76-77).

${ }^{4}$ For digital facsimiles of the manuscript and the transcriptions, see Kiernan (2019).

${ }^{5}$ For examples, see Shippey \& Haarder (1998).

${ }^{6}$ For a complete list of these editions, see Fulk (2008: 475).

${ }^{7}$ For bibliographical coverage of the scholarship, consult especially Greenfield \& Robinson (1980), Short (1980), Hasenfratz (1993), and the Old English Newsletter Bibliography Database (OEN, 2019).

${ }^{8}$ Consult Sauer (2011). For studies of translations, see Osborn (1997: 341-372) and Magennis (2011). Note that the south Saami version of the poem (McGuinne 2019) is 
complete and three partial translations were produced between 1959 and 2006 (Sauer 2011: 135-136); in English, over twenty verse translations have been produced since 1950, the most recent appearing in 2017 (Mitchell 2017). ${ }^{9}$ And translation, of course, facilitates the transmission of one culture into another and serves as a conduit of the original text to all levels of society and to numerous audiences. One of those audiences is artists. Working in multiple media such as literature, art, music, television, and film, they have reacted with varying degrees of success and persuasive power to the Old English masterpiece.

In literature, dozens of poems, plays, novels, stories, retellings, paraphrases, and imaginative recreations have emerged in English, Chinese, Czech, Danish, Dutch, German, Italian, Japanese, Latin, Portuguese, and Spanish (see Sauer 2011: 69-79)..$^{10}$ In English in 1830, Alfred Lord Tennyson was the first to put pen to paper while pondering Beowulf. Here is his translation of lines 258-262 of the poem, quoted in Magennis (2011: 62):

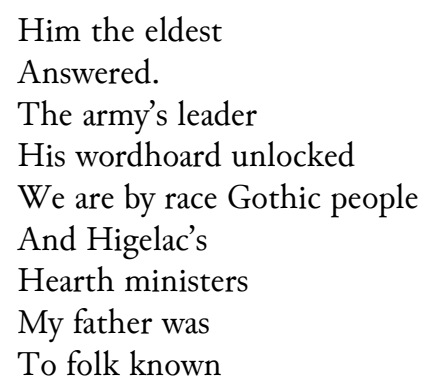

In 1838, Henry Wadsworth Longfellow followed suit with a translation of lines 189-257 (Shippey \& Haarder 1998: 223-226), but it was not, as Marijane Osborn points out, until well into the twentieth century that major poets would turn their attention to Beowulf. Richard Wilbur was the first to do so in 1948, then Wallace Stevens in 1950, Edwin Morgan in 1953, Kingsley Amis -in a satirical way- in 1957, W. H. Auden in 1962, and Kenneth Rexroth in 1965 (Osborn 1997: 352). Seamus Heaney, of course, wrote poems based on Beowulf and produced the most important English translation of the poem ever created (Sauer 2011: 49-52). Of the lesser known poets to have taken an interest Beowulf, Maureen Duffy published a poem from the dragon's point of view in

a translation of Rob Lloyd Jones's (2009) retelling for children.

${ }^{9}$ Facing-page English translation of the text from Fulk (2008).

${ }^{10}$ For a Saami translation of a retelling, see note 8 above. 
2010 (Sauer 2011: 85), and in 1980 Maurice Sagoff issued a light-hearted synopsis of the epic in his book Shrinklits, a compendium of "seventy of the world's towering classics cut down to size". The first two lines of that synopsis read

Monster Grendel's tastes are plainish.

Breakfast? Just a couple Danish.

(Sagoff 1980: 20) $)^{11}$

Four English playwrights have also been attracted to Beowulf beginning with Percy Mackaye in 1899 with his Beowulf: An Epical Drama of Anglo-Saxon Times and ending (to date) with David Calcutt's Beowulf: A Play Based on the AngloSaxon Epic Poem from 2001 (Sauer 2011: 81). ${ }^{12}$ But novelists and short-story writers have made the most use by far of the Old English poem beginning with John O. Beaty in his 1937 novel Swords in the Dawn: A Story of the First Englishmen, which utilizes the Finnsburg material in Beowulf (Osborn 1997: 351). Several other novels and stories followed, ${ }^{13}$ and since 2008 , several more, some told from the point of view of other characters in and not in the poem. Wealtheow's is offered in Ashley Crownover's Wealtheow: Her Telling of Beowulf (2008), Grendel's mother's in Susan Signe Morrison's Grendel's Mother: The Saga of the Wyrd-Wife (2015) and in Diana Stout's Grendel's Mother (2016), Freawaru's - Hrothgar's daughter mentioned just once in the original text at line 2022 - in "The Women of Beowulf" trilogy by Donnita L. Rogers: Faces in

${ }^{11}$ Blackistone (1977) is a poetic parody of Beowulf; Tegethoff (1971) is a German translation in which "[t]he Old English words are substituted by their German etymological equivalents; very strange" (Sauer 2011: 105); and an undated poem by the late linguist J. J. Lambert published here for the first time is a paean for Grendel's mother by her son, Grendel Æglæca. The poem is titled "Modor" (mother) and can almost be sung to the melody of Nate King Cole's " $\mathrm{L}$ is for the way you look at me":

$\mathrm{M}$ is for the magas you have eten [kinsmen you have eaten].

$\mathrm{O}$ is for the orcneas that you lufode [monsters that you loved].

$\mathrm{D}$ is for the deaðdagas you beorbtnode [death-days you brightened].

$\mathbf{O}$ is for the orre weras you've slagen [other men you killed].

$\mathbf{R}$ is for the reced you have wreckéd [hall you have wrecked].

Put them all togadre: they spell Modor, and Modor means all the weorold to me.

${ }^{12}$ There are also three plays in German that are based on Beowulf; see Sauer (2011: 113114).

${ }^{13}$ See Osborn (1997: 352-353) and Sauer (2011: 81-84), for a listing of these to 2007. 
the Fire (2013), Fanning the Flames (2014), and Cloak of Ashes (2015), and Grendel's sister in Susan Thurston's Sister of Grendel (2016). Maria Dahvana Headley published the latest Beowulf novel in English, The Mere Wife (2019), a modern retelling of the story.

Two of these imaginative recreations of Beowulf, however, will be the most familiar to most readers: John Gardner's (1971) novel, Grendel, and Michael Crichton's (1976) novel, Eaters of the Dead: The Manuscript of Ibn Fadlan Relating His Experiences with the Northmen in A.D. 922. The first is justly famous for its point of view (Grendel's) and wit and demonstration of a deep understanding of the original text; the second became famous as the source of an Antonio Banderas movie "The 13th Warrior" (1999), the title of which comes from line 2404 of the original text and refers either to the thief who stole the precious cup that occasioned the dragon's wrath or to the thief s owner. In the poem, "the 13th warrior" leads Beowulf and his men to the dragon's lair. Both novels have been reprinted, reviewed, and studied (see Sauer 2011: 82-83); ${ }^{14}$ both have been transmuted into other arts forms (see below under music and film); and Crichton's novel was translated into German as Schwarze Nebel (1998).

Finally, within literature and bridging the gap to art are comic books and graphic novels (Sauer 2011: 85-86). The first comic strip based on Beowulf was in Italian, Enrico Basari's and Kurt Caesar's "Beowulf: Leggenda cristiana dell'antica Danimarca cineepopea erotico", in 1941. This fact may seem strange, but the Italians took an early interest in Beowulf as evidenced by their having produced four partial and eight complete translations of the poem between 1833 and 2003 (Sauer 2011: 115-117). ${ }^{15}$ Another comic strip treatment of it did not appear until 1975 in the DC Comics series Beowulf: Dragon Slayer by Michael Uslan and Ricardo Villamante. ${ }^{16}$ The first graphic novel based on Beowulf is Jerry Bingham's Beowulf: Adapted from the $8^{\text {th }}$ Century Epic Poem in 1984, but arguably the most famous of the graphic novels devoted to the poem is that by Gareth Hinds, first published in three issues from 1999-2000. The Collected Beowulf contains With Grimmest Gripe, Gear of War, and Doom of Glory. ${ }^{17}$ Since 1975 and the publication of Uslan's and Villamante's series, the poem or its characters

\footnotetext{
${ }^{14}$ See also Frantzen (2010), George (2010: 115-119), and Killilea (2015-2016).

${ }^{15}$ On Basari's and Caesar's comic, see Osborn (1997: 351).

${ }^{16}$ For a study of the series, see Clarke (2010).

${ }^{17}$ For studies of Beowulf in the comics and graphic novels, see Torregossa (2018). On Hinds' work, see Killilea (2015-2016: 61-64).
} 
(such as Grendel) make their appearances in over a thousand comics in eleven countries according to the Grand Comics Database. ${ }^{18}$ Scholars have been studying Beowulf in the comics since 1953 (see Overton 1953).

In art, a profusion of images has cascaded out of books, album covers, dust jackets, comic books, video games, board games, and websites, and occasionally onto canvas. Simply entering the term "Beowulf" into a web browser yields an overwhelming number of illustrations of the hero, Grendel, Grendel's mother, the dragon, Wiglaf, and other Beowulfian entities. The first of this profusion are the line drawings of cultural artifacts accompanying Wentworth Huyshe's 1907 translation, Beowulf: An Old English Epic (the Earliest Epic of the Germanic Race) (see Echard 2010). One of the most recent is the depiction of a pretty punk Beowulf ripping the arm off a very vampire-like Grendel. ${ }^{19}$ In between come a plethora of portrayals that sometimes reflect the ideology, sometimes the interpretative stance of the artist. We have Brian Froude's (1975) Native American Beowulf, for example, and Lynd Ward's (1939) Jungenstil Beowulf to accompany William Ellery Leonard's translation, and Julio Castron's (1965) Don-Quixote-like rendering of the hero to illustrate Jose Luis Herrara's Spanish translation, Beowulfo. ${ }^{20}$ The pictorial representation of Beowulf simply rolls on and on, unabated.

In music, one of the most important American composers of the twentieth century and the Director of the Eastman School of Music in New York, Howard Hanson, was the first to turn his attention to Beowulf. Having read William Morris's and A. J. Wyatt's (1895) translation of the poem during a trip to England, he felt strongly that the poem - especially its wrenching conclusioncried out for musical interpretation by chorus and orchestra (Hanson 1963: 15). The 1925 "Lament for Beowulf", which is the first migration of the poem into a non-representational art form, is the result (Hanson 1925). This riveting, haunting choral work constitutes Hanson's interpretation of the last forty lines of the Morris/Wyatt translation, which begin,

\footnotetext{
${ }^{18}$ A search for "Grendel", for example, yielded 1,112 results (https://www.comics.org/ searchNew/?q=Grendel) (accessed 15 July 2019).

${ }^{19} \mathrm{See}$ https://www.independent.co.uk/news/science/archaeology/features/feastingand-fighting-the-long-lost-secrets-of-beowulf-8784510.html (accessed 16 July 2019).

${ }^{20}$ See plates 11 (Froude), 4 (Ward), and 3 (Castro) in Osborn (1997). Consult as well her discussion of the illustrations of Beowulf on pp. 355-357.
} 
For him, then, they geared the folk of the Geats, A pile on the earth all unweak - like that was, With war helms behung, and with boards of the battle, And bright byrnies, e'en after the book that he bade.

(Morris \& Wyatt 1895: 273)

Another twenty-nine years would pass before a second musical tribute to Beowulf was produced (Beach1954) and another sixteen before Hasty Pudding Theatricals at Harvard created a third in 1970 (Hasty Pudding 1970). Many more have followed to the year 2019. ${ }^{21}$ Two more choral works in addition to Hanson's appeared, one by Samuel Sørensen in 2007 and based on Ian Serraillier's (1954) retelling of the poem entitled Beowulf the Warrior (Sørensen 2007), and one by Ezequiel Viñao in 2009 focusing on Scyld's burial and commissioned by the National Chamber Choir of Ireland and the Cork International Choral Festival (Viñao 2009). Three rock musicals or rock operas (Wylie \& Davies 1974, Pickering \& Cole 1986, Pickett \& Turner 2005) and a number of operas also emerged. ${ }^{22}$ And songs about Beowulf have been written and performed by bands and artists such as Dunwich, the Italian symphonic metal hard rock band in 2008, History for Music Lovers, who told the story of Beowulf to the music of Nena's "99 Luftballons" against a backdrop of scenes from the 1999 film "The 13th Warrior" in 2010, and Aëndil, the Spanish folk metal band from Madrid, who first recorded its tribute to the Old English epic in 2017. ${ }^{23}$ The History for Music Lovers creation is especially compelling and especially useful in the classroom.

The 1974 rock musical — Beowulf: A Musical Epic- is likewise compelling and loosely based on the entire poem itself. The following song, sung by the

${ }^{21}$ For a list of most of those to 2010, see Sauer (2011: 90-91). For additional items, see also https://en.wikipedia.org/wiki/List_of_translations_and_artistic_depictions _of_Beowulf (accessed 3 June 2019).

22 For a list of opera and theater adaptations, see https://en.wikipedia.org/wiki/ List_of_translations_and_artistic_depictions_of_Beowulf (accessed 10 June 2019). Only three of the operas will be dealt with in the present essay: Goldenthal (2006), Lash (2016), and Byers (2018).

23 Dunwich's song "Beowulf" from its 2008 album, Heilagmanoth (https:/www.youtube.com/watch?v=aaAQXuG4a2o); "Beowulf (99 Luftballons by Nena)” 2010 (https://www.youtube.com/watch?v=yiBaSqO7n9U); Aëndil "Beowulf y Grendel” 2017 (https://www.youtube.com/watch?v=GqqU9g_9kho) (accessed 10 June 2019). 
chorus after Grendel's defeat by Beowulf, crystalizes the essential qualities of this rollicking, banjo-plucking, Canadian transmutation - a kind of "Beowulf Meets Jesus Christ Superstar" rendition of the tale:

Farewell, Grendel.

Die well, Grendel.

We have your arm,

So we'll wave goodbye.

Grendel, you are free to die.

Bye Grendel, die Grendel.

Armless, charmless, harmless, Grendel.

Single-minded hero, single-handed hero,

Started with two

And now he has three.

Clap all your hands now —one, two, three.

Bye, Grendel, die Grendel.

Armless, charmless, harmless, Grendel.

Armless, charmless, harmless, Grendel.

Armless, charmless, harmless, Grendel.

(Wylie \& Davies libretto 1974)

Two of the operas produced thus far focus on Grendel. Elliott Goldenthal, the well-known composer who won an Oscar and Golden Globe Award for his score for the film Frida and who was nominated for Golden Globe Awards for his scores for Interview with the Vampire (1994) and Michael Collins (1996), worked on Grendel: Transcendence of the Great Big Bad for twenty years before it debuted in Los Angeles and New York in 2006. The opera is based on John Gardner's (1971) novel Grendel, which tells the Beowulf story from Grendel's point of view, and was eagerly anticipated. The great bass-baritone Eric Owens would play Grendel and Desmond Richardson, the equally great American dancer, would play Beowulf, both performing in a lavishly designed production conceived by the opera's director, Julie Taymor. The result, however, disappointed most who saw it, and the opera has not been performed since, nor, unfortunately, was it recorded. ${ }^{24}$

Not as lavishly produced but preserved on YouTube, Barbara Byers' onehour-and-thirty-four-minute Beowulf: A Folk Metal Opera from 2018 follows

${ }^{24}$ For analyses of the opera, see Frantzen (2010: 155-163) and George (2010: 120-121). 
“the lead of John Gardner's work 'Grendel' (1971), which explores ideas of fatalism, nihilism and the existential crisis in the context of the monsters of Beowulf". The opera "presents the tragedy of the monster Grendel, illuminating his cruel birth as an always-other to the humans, created by humans, storied, demonized and finally killed by humans". ${ }^{25}$ The story is accompanied by a musical ensemble of piano, percussion, double bass, baritone saxophone and oboe, flute, and electronics. Byers narrates the tale, and the characters in it Grendel, Wealtheow, Hrothgar, Aeschere, a Sybil, and the Norns- are all played by humans. Beowulf, Odin, and the dragon are not. Beowulf is made of chicken wire, papier-mâché, and paint. Odin consists of pvc pipe, rope, canvas, memory foam, and paint. And the dragon (or Time or Existence) is constructed of bamboo, "found objects", and electrical wires. ${ }^{26}$

The third operatic treatment of Beowulf dealt with here comes in 2016 from Hannah Lash, who is on the faculty of the Yale School of Music and is a wellknown composer. A performance of the twenty-five-minute opera with Lash conducting is available, ${ }^{27}$ as is the libretto for it. ${ }^{28}$ The chamber opera is a modernized version of the Beowulf story, very loosely based on the Old English epic. In Lash's treatment, Beowulf is a physician suffering from PTSD and consequent flashbacks after serving as an army medic in a war abroad and failing to save an injured child. He also cares for his elderly mother, who has suffered a stroke, and eventually in an act of mercy, he administers enough morphine to her to ease peacefully into death in his arms. Rather than glorifying the hero, the opera "paints a true-to-life portrait of him, replete with the emotional pain from which he suffers" ${ }^{29}$ as he battles the monster time and his feelings of helplessness in the face of his mother's deteriorating health. This innovative, provocative work was well reviewed by, for example, The Boston Globe on May $21,2016 .^{30}$

\footnotetext{
${ }^{25}$ See http://musicweb.ucsd.edu/concerts/concert_programs/2017-8/Spring\%202018/ 20180518-Byers.pdf (accessed 11 June 2019).

${ }^{26}$ Ibid.

${ }^{27}$ See https://www.youtube.com/watch?v=qiguVgTIVeQ\&list=PLwBwpPufjYsM WEvNkZEUyn0LwannLoI3A\&index=2 (accessed 11 June 2019).

${ }^{28}$ See http://guerillaopera.com/wp-content/uploads/2016/05/Beowulf-Libretto-NewWebsite.pdf (accessed 12 June 2019).

${ }^{29}$ Ibid.

${ }^{30}$ A fourth work intended to be an opera also bears mention, Craton (2005-2011), who observes that: "[i]nitially the music which forms the Beowulf orchestral suite was planned for an opera based on the life of the hero from the medieval epic poem of the
} 
The final musical treatment of Beowulf to be touched on here is the utterly faithful performance of it in Old English by Benjamin Bagby. A trained academic and musician, Bagby combines his scholarly, philological understanding of the poem with his knowledge of medieval music to reconstruct a hypothetical performance plausibly close to how the epic may have been originally performed (Bagby 2005). Bagby plays the role of an Anglo-Saxon scop plucking a six-string harp and singing and reciting the first 1062 lines of the text. The harp is based on a historical understanding of the instrument and a seventh-century archeological find near Stuttgart (George 2010: 124), and the music is improvised and tied to the meter of the poem. Bagby first performed Beowulf in 1990, and his 2006 performance in Sweden is available on DVD.

Beowulfs fourth migration into a medium not its own occurs on television beginning in 1966, when the story was read in its entirety. This occurred in five fifteen-minute episodes on BBC One's "Jackanory", a series dedicated to getting children interested in reading. Ten years later in the 1 February 1976 episode of "The Six Million Dollar Man" titled "The Secret of Bigfoot: Part 1", ${ }^{31}$ part of the story appears on television again. In this episode, astronaut Steve Austin part man, mostly machine- searches for two missing geologist friends in California and confronts a recalcitrant Sasquatch, played by André the Giant. The two wrestle fiercely, Austin ultimately ripping off the Sasquatch's arm in a scene unmistakably from Beowulf. As fanciful as it may seem to equate Grendel and Bigfoot, work has since been devoted to the hypothesis that the two are actually one in the same (Mooney 1980, Duncan 1994). The magic of television thus adumbrates the imaginative reaches of scholarship.

Nearly thirty years would pass before Beowulf appeared on television again, this time on "Mighty Max", the animated American television series based on the British Mighty Max toys. In the episode "The Maxnificent Seven", which aired on 8 December 1993, Max chooses Beowulf (a washed-out professional wrestler in Denmark) as one of seven heroes to help him battle Skullmaster, his nemesis. ${ }^{32}$ Less than two years later on 24 April 1995 in season one, episode

same name. The operatic treatment, however, has been put on hold due to not yet having found a suitable libretto. The movements that comprise the present work were intended to be instrumental entr'actes within the larger opus itself, but for now they have been combined to form a suite that tells the story of our hero's life without words." ${ }^{31}$ See https://www.imdb.com/title/tt0073677/ (accessed 14 June 2019).

32 See https://www.thewatchcartoononline.tv/mighty-max-season-1-episode-13-themaxnificent-seven (accessed 19 June 2019). 
eleven of "Star Trek Voyager" titled "Heroes and Demons", ${ }^{33}$ Beowulf appears once again along with Hrothgar and Unferth and Hrothgar's daughter Freawaru but misnamed "Freya". Running a holonovel based on Beowulf, Ensign Kim enters it, is followed by two more crew members and finally by the Doctor, who engineers a peaceful accord with a malevolent photonic energy formation called Grendel. An animated but otherwise much more faithful adaptation of Beowulf appeared in 1998. The impressive and compact "Animated Epics: Beowulf" boasts a screenplay by Murray Walls, narration by Derek Jacoby, and voice-over for Beowulf by Joseph Fiennes. Professor Derek Brewer of the University of Cambridge served as advisor to assure the fidelity of the movie to the original text (Walls 1998). In 2007, another film for television was aired, this one only loosely based on Beowulf and titled "Grendel" or "Beowulf et la Colère des Dieux". The low-budget film was made for the SyFy channel. ${ }^{34}$

With the advent of the twenty-first century, the whole of Beowulf is not seen on television but the main character of the poem is. He appears in "Xena: Warrior Princess" in 2000 in season six, episodes seven ("The Rheingold"), eight ("The Ring"), and nine ("Return of the Valkyrie"), where he joins forces in the far north with Xena to vanquish Grindl and her son. ${ }^{35}$ Grindl is the Valkyrie Grinhilda, transformed into a monster in Xena's evil past by a ring made of the Rheingold gold. And in the thirteenth episode of ABC's "Once Upon a Time" in season six in 2017, "Ill-Boding Patterns", Beowulf appears again, this time wielding Hrunting in the first War against the Ogres. On the verge of defeat, he is saved by Rumplestiltskin, who himself is aided by dark magic in slaying all the ogres and eventually breaking the neck of an unheroic Beowulf as well. ${ }^{36}$ Most significantly, Beowulf stars in "Beowulf: Return to the Shieldlands", the short-lived television series produced in the UK in 2016. Loosely based on the

\footnotetext{
${ }^{33}$ See https://www.netflix.com/title/70178053 (accessed 19 June 2019).

${ }^{34}$ See https://www.syfy.com/syfymovies/videos/101-grendel (accessed 20 June 2019).

${ }^{35}$ See https://www.amazon.com/Whos-Gurkham/dp/B01JTFV68Q/ref=sr_1_1 ?crid= 2GBXZ5QHHDQCF\&keywords=xena+season+6\&qid=1561015808\&s=instant video\&sprefix $=$ Xena\%2Cinstant-video\%2C317\&sr=1-1 (accessed 20 June 2019). The other episodes are available on Amazon as well.

${ }^{36}$ See https:/www.amazon.com/gp/product/B06XQSS1MY?ie=UTF8\&csrfToken =g14f1uN\%205dsNrmIpYuFNLTBNbJ4vnueMfAPILZ\%2FnQ9eBAAAACQAAAAB dCjtXcmF3AAAAABVX8CwXqz4nuL9RKX\%2F\%2F\%2Fw\%3D\%3D\&offerASIN= B06XQSS1MY\&purchasetoken=xBREpNzQYHxwHXjUhaPAG\%2BaL\%2BR\%2FA ZzP2naQgdVvne1E\&triggerPurchase=1\& (accessed 20 June 2019).
} 
poem, with many new characters and plots and receiving mixed reviews, the series lasted for just one season of twelve episodes. ${ }^{37}$

The fifth but undoubtedly not the last migration of Beowulf into other art forms finds him at the movies, first in Don Fairservice's faithful but neglected adaptation of the poem to film in Kevin Crossley-Holland's translation in $1976^{38}$ and then in 1977 in a single word in the Academy-Award-winning "Annie Hall". ${ }^{39}$ In scene nineteen, "Out to the Hamptons", Annie sits and Woody reclines on the bed, chatting, Annie searching through a course catalogue and Woody reading the newspaper. "Does this sound like a good course?" Annie asks. "Um, 'Modern American Poetry'? Or ... let's see now ... maybe I should take 'Introduction to the Novel' [...]"; Woody quickly interjects, "Just don't take any course where they make you read Beowulf".

Annie may have taken Woody's advice, but not everyone else has. In 1981, an Australian filmmaker turned his attention to the poem via John Gardner's novel. The result is a whimsical, highly amusing animated feature film titled "Grendel, Grendel, Grendel". Peter Ustinov provides the voice for both Grendel, who is the film's narrator, and the dragon, who is Grendel's mother. ${ }^{40}$

Less whimsical is Christopher Lambert's (of "Highlander" fame) futuristic "Beowulf" from 1998, ${ }^{41}$ which is loosely based on the first half of the poem and takes place in a post-apocalyptic world ravaged by Grendel and his mother, played by Layla Harvest Roberts, a former Playboy Playmate. ${ }^{42}$ From 1999, Antonio Banderas's "The 13th Warrior" likewise is only loosely based on the

\footnotetext{
${ }^{37}$ See https://www.imdb.com/title/tt4520906/ (accessed 20 June 2019).

${ }^{38}$ George (2010: 139), where the film is inaccurately dated 1973.

${ }^{39}$ The IMDB lists the 1967 Japanese animated children's movie "Shônen Jakko to Mahôtsukai" as based on Beowulf (a dubbed English version, "Jack and the Witch", is available), and that would make the movie the first to allude to, be influenced by, or mention Beowulf. The connection, however, is extremely difficult to see. A very distant echo of Beowulfs fight with Grendel's mother may be there but little if anything else. ${ }^{40}$ See https://www.youtube.com/watch?v=QctdXsSLPvI (accessed 21 June 2019). Two other films from the 1980s, "Clash of the Titans" (1981) and "Predator" (1987), the latter starring Arnold Schwarzenegger, have been said to contain some parallels to Beowulf. The first has clearly adapted the three monster fights to the Perseus legend, but the supposed parallels in the second seem too distant to be persuasive. George (2010: 127) lists some of those for "Predator".

${ }^{41}$ See https://www.imdb.com/title/tt0120604/ (accessed 21 June 2019).

${ }^{42}$ On Grendel's mother in these two movies and in Gunnarsson's Beowulf and Grendel and in Zemeckis's Beowulf, see Peña Gil (2011).
} 
poem following instead Michael Crichton's 1976 novel The Eaters of the Dead: The Manuscript of Ibn Fadlan Relating bis Experiences with the Northmen in A.D. 922. Novel and film take the view that Grendel symbolizes a cannibalistic tribe that plagued Denmark in prehistory. ${ }^{43}$ Finally in 1999, "The Male Swagger", apparently a comedy, debuted. Featuring Beowulf, Wulfgar, Wealtheow, hall thanes, Jesus Christ, Malcom X, Sir Lardalot, and Alex Trebek among others, the film seems to be lost to history except for its essential details. ${ }^{44}$

At the beginning of the new millennium, several filmmakers capitalized on the huge popularity of Nobel laureate Seamus Heaney's 1999 translation of Beowulf, which became a New York Times bestseller. The Icelander Sturla Gunnarsson turned the first part of the poem - the Grendel story - into the 2005 film, "Beowulf and Grendel", a rendition that has tremendous scenery, little fidelity to the text, and Grendel as a Neanderthal man. Another seeming flight of movie-making fantasy actually has its antecedent in serious scholarship. One of the reviewers of the first edition of the poem in 1815 postulated that the monster symbolizes a primitive human (Peter Eramus Müller 1815, apud Shippey \& Haarder 1998: 106). Another film based on Beowulf, "Blade of the King", would have appeared in 2005 or shortly thereafter but only made it as far as a brief concept film to attract potential investors. ${ }^{45}$

Investors do seem to have taken interest in Robert Zemeckis's (2007) movie of the entire poem that boasts a stellar cast, including Anthony Hopkins, John Malkovich, and Angelina Jolie, great fidelity as well as artistic infidelity to the text, and an outrageously believable dragon. This film "is the first full-length motion picture to use performance capture technology entirely from beginning to end" (Jones 2010: 18), so it is significant in the history of film. It was well received for the most part, but some criticized it on at least three counts: the dialogue, the sex, and the portrayal of Hrothgar as Grendel's father. All the alterations were made to make the film more appealing to a contemporary audience. The dialogue - which I found to be witty - has to be defended on that ground alone. But the other two can be defended by referring to past scholarship on the poem. Regarding an extremely sensual, sexual, seductive

\footnotetext{
${ }^{43}$ Again, scholarly commentary on the poem anticipates the work of the creative writer. See Peter Eramus Müller (1815, apud Shippey \& Haarder 1998: 106). See also Stopford Brooke in Shippey \& Haarder (1998: 486-487).

${ }^{44}$ See https://www.imdb.com/title/tt0221371/fullcredits?ref_=tt_cl_sm\#cast (accessed 21 June 2019).

${ }^{45}$ See https://www.youtube.com/watch?v=Tb0-Ei2JK5E (accessed 27 June 2019).
} 
Grendel's mother, serious scholars have argued that she may represent dangerous sexual appetites (see Crépin 1983: 51-60, 1991: 485; also Chance 1980). Angelina Jolie or a Playboy Playmate seem appropriate choices for portraying such a mother. Regarding Hrothgar's having fathered Grendel, at least one scholar has made a similar argument in his critique of heroism in the poem, claiming that Grendel's mother is Hrothgar's sister and that Grendel is the product of their incestuous relationship (Fajardo-Acosta 1989: 57). Whatever the film's flaws are, however, even if adumbrated in scholarship, its having brought Beowulf to such a massive audience worldwide is its greatest virtue. ${ }^{46}$

Of the four films following the Zemekis version that pertain in any way to Beowulf, two are only distantly related. Beowulf appears briefly toward the end of "Disaster Movie" (2008), ${ }^{47}$ and one of the last four humans on earth battling robots in "The Rise of the Robots" (2015) ${ }^{48}$ is named Professor Beowulf. "Beowulf: Prince of the Geats" (2007), ${ }^{49}$ however, is a serious though lowbudget retelling of the tale that benefitted the American and Norwegian cancer societies and uniquely features a black Beowulf played by Jayshan Jackson and Damon Lynch III. And the big-budgeted "Outlander" (2008) is a science-fiction adaptation, loosely based on the first half of Beowulf, which opens with a space craft from a distant world crashing into a lake in eight-century Norway. From it emerge Kainan, the Beowulf figure, and the Moorwen, the Grendel figure, a stowaway that starts immediately ravaging villages. Jim Caviezel plays Kainan and John Hurt, Rothgar. Freawaru appears once more as Freya. ${ }^{50}$

The influence of Beowulf, then, is vast and continuing and dynamic, its reception history constantly evolving. At least four countries have claimed the

\footnotetext{
${ }^{46}$ For more on the Zemekis film, see George (2010: 133-142) and Jones (2010: 18-29).

${ }^{47}$ See https://www.imdb.com/title/tt1213644/ (accessed 27 June 2019).

${ }^{48}$ See https://www.youtube.com/watch?v=pi33SFFF5LI (accessed 27 June 2019).

${ }^{49}$ See https://www.bing.com/videos/search?q=beowulf\%3a+prince+of+the+geats\&view $=$ detail $\&$ mid $=9743 \mathrm{D} 7 \mathrm{C} 304 \mathrm{D} 3 \mathrm{EBBAF} 40 \mathrm{E} 9743 \mathrm{D} 7 \mathrm{C} 304 \mathrm{D} 3 \mathrm{EBBAF} 40 \mathrm{E} \& \mathrm{FORM}=\mathrm{VIRE}$ (accessed 27 June 2019).

${ }^{50}$ See https://www.imdb.com/title/tt0462465/?ref_=nv_sr_2?ref_=nv_sr_2 (accessed 28 June 2019).
} 
poem as their own: Denmark, ${ }^{51}$ Germany, ${ }^{52}$ England, ${ }^{53}$ and Sweden. ${ }^{54}$ At least three rock bands - one Dutch, one Finnish, and one Australian - are named "Grendel"; bullets and rifle parts, dogs and cats have received the same name or "Beowulf"; a Kick Starter drive to fund the development of a "Beowulf" board game was launched in 2014; $;^{55}$ license plates bear Beowulf s name; and one can purchase "Got Beowulf?" and "\#Beowulf" mugs, a Beowulf-cluster software operating system, or the services of Beowulf Mining to explore natural resources in the Nordic region. ${ }^{56}$ The appropriations seem endless. But one of the most striking of them appeared in the June 2004 issue of Esquire, a magazine dedicated to men's fashion, cocktails, politics, and entertainment. There, reclining on stomach and elbows in a bikini and spiked heels, lovingly holding an open copy of a translation of the epic, Carmen Electra smiles coquettishly out at her audience (Chiarella 2004: 116-117). ${ }^{57}$ The accompanying article mentions neither poem nor photo. The photo, however, dramatically testifies to just how profoundly Beowulf has affected our entire world - from scholars and poets, artists and merchants to glamorous actresses- ever since Thorkelin first brought it to our attention in 1815 .

\section{References}

Anonymous 1897: Fonden ad usus publicos, Vol. 1. Copenhagen, C. A. Reitzel.

Baatz, C. 2014: Beowulf in Deutschland Zur literarischen und wissenschaftlichen Rezeption altenglischer Literatur in Deutschland am Beispiel des Beowulf. (Dissertation.) University of Tübingen.

\footnotetext{
${ }^{51}$ E.g. Thorkelin's first edition of the poem, the title of which specifies the poem as being Danish in the Anglo-Saxon dialect.

${ }^{52}$ E.g. see the title of Leo (1839) making the poem the oldest German epic. On the proto-Nazi claim on Beowulffor the German people, see Osborn (2006). On the German reception history of Beowulf, see Baatz (2014).

${ }^{53}$ E.g. Kemble (1833).

${ }^{54}$ E.g. Gräslund (2018). See also Bjork (1997: 114ff.).

${ }^{55}$ See https://www.kickstarter.com/projects/827765657/beowulf-a-board-game/ updates (accessed 2 June 2019).

${ }^{56}$ See https://beowulfmining.com (accessed 15 June 2019).

${ }^{57} \mathrm{I}$ am grateful to Dr. Karen Bollerman for alerting me to this article and picture.
} 
Bagby, B. 2005: Beowulf, the Edda and the Performance of Medieval Epic: Notes from the Workshop of a Reconstructed 'Singer of Tales'. In E. B. Vitz, N. Freeman Regaldo \& M. Lawrence eds. Performing Medieval Narrative. Cambridge, D. S. Brewer: 181-192.

Beach, B. C. 1954: Beowulf: A Symphonic Sketch for Band by Bruce C. Beach. New York, Remick Music Corporation.

Bjork, R. E. 1996: Grímur Jónnson Thorkelin's Preface to the First Edition of Beowulf, 1815. Scandinavian Studies 68: 291-320.

Bjork, R. E. 1997: Nineteenth-Century Scandinavia and the Birth of Anglo-Saxon Studies. In A. J. Frantzen \& J. D. Niles eds. Anglo-Saxonism and the Construction of Social Identity. Gainesville, University Press of Florida: 111-132.

Blackistone, B. 1977: Beowabbit. Takoma Park, MD, n.p.

Byers, B. 2018: Beowulf: A Folk Metal Opera. https://www.youtube.com/watch? $\mathrm{v}=$ MOBhapR3yJs. [Accessed 10 June 2019]

Chance, J. 1980: The Structural Unity in Beowulf: The Problem of Grendel's Mother. Texas Studies in Literature and Language 22: 287-303.

Chiarella, T. 2004: A Fling with Carmen Electra. Esquire 142.6: 116-117.

Clark, D. \& N. Perkins eds. 2010: Anglo-Saxon Culture and the Modern Imagination. Cambridge, Boydell \& Brewer.

Clarke, C. A. M. 2010: Re-placing Masculinity: The DC Comics Beowulf Series and its Context. In D. Clark \& N. Perkins eds. Anglo-Saxon Culture and the Modern Imagination. Cambridge, Boydell \& Brewer: 165-182.

Craton, J. 2005-2011: Beowulf: The Orchestral Suite. http://www.craton.net/music /beowulf/. [Accessed 12 June 2019]

Crépin, A. 1983: La Consience de soi héroique: L'example de Beowulf. R. Ellrodt, ed. Genèse de la conscience moderne: Études sur le développement de la conscience de soi dans les littératures du monde occidental. Publications de la Sorbonne (Série Littérature 14 Paris), Presses Universitaires de France: 51-60.

Crépin, A. 1991: Beowulf: édition diplomatique et texte critique, traduction française, commentaire et vocabulaire (Göppinger Arbeiten zur Germanistik 329). 2 vols. Göppingen, Kümmerle.

Duncan, E. 1994: Was Grendel a Bigfoot? McNeese Review: 91-99.

Fajardo-Acosta, F. 1989: The Condemnation of Heroism in the Tragedy of Beowulf: A Study in the Characterization of the Epic (Studies in Epic and Romance Literature 2). Lewiston (NY), Edwin W. Mellen Press.

Echard, S. 2010: Boom: Seeing Beowulf in Pictures and Print. In D. Clark \& N. Perkins eds. Anglo-Saxon Culture and the Modern Imagination. Cambridge, Boydell \& Brewer: $129-146$.

Frantzen, A. J. 2010: Window in the Wall: Looking for Grand Opera in John Gardner's Grendel. In D. Clark \& N. Perkins eds. Anglo-Saxon Culture and the Modern Imagination. Cambridge, Boydell \& Brewer: 147-164. 
Fulk, R. D. ed. and trans. 2010. The Beowulf Manuscript (Dumbarton Oaks Medieval Library 3). Cambridge (MA), Harvard University Press.

Fulk, R. D., R. E. Bjork \& J. D. Niles eds. 2008. Klaeber's Beowulf and the Fight at Finnsburg. 4th ed. Toronto, University of Toronto Press.

George, J.-A. 2010: Beowulf: A Reader's Guide to Essential Criticism. New York, PalgraveMacMillan.

Goldenthal, E. 2006: Grendel: Transcendence of the Great Big Bad. Los Angeles, n.p.

Gräslund, B. 2018: Beowulfkvädet. Den nordiska bakgrunden. Uppsala, Kungl. Gustav Adolfs Akademien.

Greenfield, S. B. \& F. C. Robinson 1980: A Bibliography on Publications on Old English Literature to the End of 1972. Toronto, University of Toronto Press.

Hanson, H. 1925: Symphony No. 2, “The Lament for Beowulf”, Opus 25. Boston, Victor Masterworks recording VM 889.

Hanson, H. 1963: Lament for Beowulf. In R. S. Hines ed. The Composer's Point of View: Essays on Twentieth-Century Choral Music. Norman, University of Oklahoma Press.

Hasentratz, R. J. 1993: Beowulf Scholarship: An Annotated Bibliography, 1979-1990. New York, Garland Publishing, Inc.

Hasty Pudding Theatricals 1970: The Boy who Cried Beowulf. Cambridge (MA), n.p.

Jones, C. 2010: From Heorot to Hollywood: Beowulf in its Third Millenium. In D. Clark \& N. Perkins eds. Anglo-Saxon Culture and the Modern Imagination. Cambridge, Boydell \& Brewer: 13-30.

Kemble, J. M. 1833: The Anglo-Saxon Poems of Beowulf, the Travellers Song, and the Battle of Finnes-burb. London, W. Pickering.

Kiernan, K. 2019: Electronic Beowulf 4.1. http://ebeowulf.uky.edu. [Accessed 1 June 2019]

Killilea, A. E. 2015-2016. Smash the matriarchy: Fear of feminine power structures in Beowulf adaptations. SELIM 21: 57-80.

Lash, H. 2016: Beowulf. https://www.guerillaopera.org/beowulf. [Accessed 10 June 2019]

Leo, H. 1839: Bëówulf, dasz älteste deutsche, in angelsächsischer Mundart erbaltene, Heldengedicht. Halle, E. Anton.

Magennis, H. 2011: Translating Beowulf: Modern Versions in English Verse. Cambridge, D. S. Brewer.

McGuinne, J. S. trans. 2019: Beowulf-Dïbte staalebke alma. Umeå, Gïelem nastedh.

Mitchell, S. trans. 2017: Beowulf. New Haven, Yale University Press.

Mooney, T. J. 1980: Is Bigfoot the Star of Beowulf? Fate 33.1: 72.

Morris, W. \& A. J. Wyatt trans. 1895: The Tale of Beowulf. Hammersmith, Kelmscott Press.

Old English Newsletter Bibliography Database (OEN) 2019: http://www.oenewsletter.org/ OENDB/advanced.php. [Accessed 1 June 2019] 
Osborn, M. 1997: Translations, Versions, Illustrations. In R. E. Bjork \& J. D. Niles eds. A Beowulf Handbook. Lincoln, University of Nebraska Press: 341-372.

Osborn, M. 2006: Bruder's Beowulf. Ein heldisches Spiel. Geardagum 26: 5-52.

Overton, G. H. 1953: 'Beowulf Can Be Fun: An Account of an Unorthodox Approach. The English Journal 42: 392-393.

Peña Gil, P. 2011: The Witch, the Ogress, and the Temptress: Defining Grendel's Mother in Beowulf and Film Adaptations. SELIM 18: 49-75.

Pickering, K. \& K. Cole 1986: Beowulf: A Rock Musical. London \& Schulenburg (Texas), I. E. Clark.

Pickett, L. \& L. Turner 2005: Beowulf: The Rock Opera. https://www.broadwayworld. com/article/BEOWULF-The-Rock-Opera-at-Irish-Repertory-Theatre-October7-November-27-20050906. [Accessed 10 June 2019]

Sagoff, M. 1980: Shrinklits: Seventy of the World's Towering Classics Cut Down to Size. New York, Workman Pub.

Sauer, H. 2011: 205 Years of Beowulf Translations and Adaptations (1805-2010): A Bibliography. Trier, Wissenschaflicher Verlag.

Shippey, T. A. \& A. Haarder eds. 1998: Beowulf: The Critical Heritage. London \& New York, Routledge.

Short, D. 1980: Beowulf Scholarship: An Annotated Bibliography. New York, Garland Publishing, Inc.

Sørensen, S. 2007: Beowulf. Part 1: Grendel. Los Angeles, Bee Guy Records.

Tegethoff, W. 1971: Der altangelsächsische Beowulf: Ein Werk Adalberts von Bremen. Osnabrück, Im Eigenverlag des Verfassers.

Thorkelin, G. J. ed. and trans. 1815: De Danorum rebus gestis seculi III \& IV (Poëma Danicum dialect Anglo-Saxonica). Copenhagen, Typis T. E. Rangel.

Torregossa, M. A. 2018: Beowulf in the Comics: An Initial Bibliographic Guide 2.0. http://www.academia.edu/Documents/in/Beowulf?page=3. [Accessed 15 July 2019]

Turner, S. 1803: A Vindication of the Genuineness of the Ancient British Poems of Aneurin, Taliesin, Llywarch Hen, and Merdbin, with Specimens of the Poems. London, E. Williams.

Turner, S. 1805: The History of the Manners, Landed Property, Government, Laws, Poetry, Literature, and Language of the Anglo-Saxons. Vol. 4. London, Longman.

Viñao, E. 2019: Beowulf: Scyld's Burial for SATB and Percussion Quartert. http://www.tloneditions.com/Ezequiel_Vinao_Beowulf_Scylds_Burial.html. [Accessed 3 June 2019]

Walls, M. 1998: Animated Epics: Beowulf. https://www.dailymotion.com/video/x6djd2r. [Accessed 19 June 2019]

Wanley, H. 1705: Librorum Veterum Septentrionalium, qui in Angliae Bibliothecis extant, nec non multorum Veterum Codicum Septentrionalium alibi extantium Catalogus Historico-Criticus, cum totius Thesauri Linguarum Septentrionalium sex Indicibus. Reprinted 1970. Hildesheim \& New York, Georg Olms. 
Wylie, B. J. \& V. Davies 1974/1983: Beowulf: A Musical Epic. Toronto, Leap Frog Records.

Wylie, B. J. \& V. Davies 1974/1983. Libretto for Beowulf: A Musical Epic. Toronto, Leap Frog Records.

\author{
Author's address \\ Department of English \\ Arizona State University \\ Tempe, AZ 85287-1401 \\ USA \\ e-mail: robert.bjork@asu.edu
}

received: 22 October 2019 revised version accepted: 11 February 2020 